\title{
Pain assessment in animal models: do we need further studies?
}

This article was published in the following Dove Press journal:

Journal of Pain Research

8 May 2014

Number of times this article has been viewed

\section{Carmelo Gigliuto' \\ Manuela De Gregori² \\ Valentina Malafoglia ${ }^{3}$ \\ William Raffaeli ${ }^{3}$ \\ Christian Compagnone ${ }^{4}$ \\ Livia Visai ${ }^{5,6}$ \\ Paola Petrini ${ }^{7}$ \\ Maria Antonietta Avanzini ${ }^{9}$ \\ Carolina Muscoli ${ }^{8}$ \\ Jacopo Viganò ${ }^{\prime \prime}$ \\ Francesco Calabrese ${ }^{\prime \prime}$ \\ Tommaso Dominioni" \\ Massimo Allegri ${ }^{2,10}$ \\ Lorenzo Cobianchi"}

'Anaesthesia and Intensive Care, University of Pavia, Pavia, 'Pain Therapy Service, Fondazione IRCCS Policlinico San Matteo, Pavia, ${ }^{3}$ SSAL

Foundation, Institute for Research on Pain, Torre Pedrera, Rimini, ${ }^{4}$ Department of Anaesthesia, Intensive Care and Pain Therapy, Azienda

Ospedaliera Universitaria Parma, University of

Parma, Parma, ${ }^{5}$ Department of Molecular Medicine,

Center for Tissue Engineering (CIT), INSTM UdR

of Pavia, University of Pavia, Pavia, ${ }^{6}$ Department of

Occupational Medicine, Ergonomy and Disability,

Laboratory of Nanotechnology, Salvatore Maugeri

Foundation, IRCCS, Veruno, 'Dipartimento di

Chimica, Materiali e Ingegneria Chimica 'G Natta'

and Unità di Ricerca Consorzio INSTM, Politecnico

di Milano, Milan, ${ }^{8}$ Department of Health Science,

University Magna Grecia of Catanzaro and Centro

del Farmaco, IRCCS San Raffaele Pisana, Roma,

'Laboratory of Transplant Immunology/Cell Factory,

Fondazione IRCCS Policlinico "San Matteo", Pavia,

${ }^{10}$ Department of Clinical, Surgical, Diagnostic and

Paediatric Sciences, University of Pavia, Pavia,

"University of Pavia, Department of Surgical, Clinical,

Paediatric and Diagnostic Science, General Surgery I,

IRCCS Fondazione Policlinico San Matteo, Pavia, Italy

Correspondence: L Cobianchi

University of Pavia, Department of Surgical,

Clinical, Paediatric and Diagnostic Science,

General Surgery I, IRCCS Fondazione

Policlinico San Matteo, Pavia, Italy

Tel +39 382502490

Fax +39 382502447

Email l.cobianchi@smatteo.pv.it
Abstract: In the last two decades, animal models have become important tools in understanding and treating pain, and in predicting analgesic efficacy. Although rodent models retain a dominant role in the study of pain mechanisms, large animal models may predict human biology and pharmacology in certain pain conditions more accurately. Taking into consideration the anatomical and physiological characteristics common to man and pigs (median body size, digestive apparatus, number, size, distribution and communication of vessels in dermal skin, epidermal-dermal junctions, the immunoreactivity of peptide nerve fibers, distribution of nociceptive and nonnociceptive fiber classes, and changes in axonal excitability), swines seem to provide the most suitable animal model for pain assessment. Locomotor function, clinical signs, and measurements (respiratory rate, heart rate, blood pressure, temperature, electromyography), behavior (bright/ quiet, alert, responsive, depressed, unresponsive), plasma concentration of substance $\mathrm{P}$ and cortisol, vocalization, lameness, and axon reflex vasodilatation by laser Doppler imaging have been used to assess pain, but none of these evaluations have proved entirely satisfactory. It is necessary to identify new methods for evaluating pain in large animals (particularly pigs), because of their similarities to humans. This could lead to improved assessment of pain and improved analgesic treatment for both humans and laboratory animals.

Keywords: pain assessment, experimental model, translational research

\section{Introduction}

To date, the majority of publications on pain research have focused on humans. The greatest limitation of this human approach is the fact that these studies are primarily aimed at characterizing states of pain, and only a small percentage directly test the anatomical, biochemical, or pathophysiological mechanisms of pain. ${ }^{1}$ If we are to make significant advances in our understanding and treatment of pain, animals provide an important resource for predicting analgesic efficacy, which can lead to the development of clinical drugs. ${ }^{2}$ The last two decades have witnessed an evolution of animal models which has improved our understanding of the pathophysiology of inflammation, peripheral nerve disease, and bone infiltration by cancer cells. ${ }^{3}$ The animal models have also encouraged multidisciplinary analysis in the field of pain studies. Although the relative importance of genetic variability in human pain perception remains unclear, it is well-known that rodent populations display large and heritable differences in both nociceptive and analgesic sensitivity. ${ }^{4}$ Improving our understanding of the genetic bases of pain-related traits may have important scientific and clinical implications, and could facilitate the development of novel analgesic strategies or improve treatment of pain using conventional therapies. The first evidence has recently been presented of 
epigenetic regulation in animals as a key factor in controlling states of pain. ${ }^{5}$ Other "-omics" techniques are currently being developed, such as metabolomics, which has recently been associated with pain in the rat model. ${ }^{6}$

Behavior resulting from pain can even be measured in decerebrate animals. ${ }^{7,8}$ Withdrawal from algogenic stimulus (spinal reflex), ${ }^{9}$ abdominal stretching and jumping (bulbspinal reflex), ${ }^{10}$ vocalization, biting, guarding, scratching, and licking (innate behaviors) are the most frequently used parameters in this type of evaluation. ${ }^{7,8}$ Unfortunately, some of these behaviors may be affected by a number of conditions (eg, reflexive withdrawal by surgical damage to motor neurons) which could affect the objectivity of the measurements, ${ }^{9,11}$ as well as their relevance to clinical pain. ${ }^{12}$

Despite the many studies conducted on small animals, more efforts are necessary to develop tools for identifying pain and evaluating its intensity and form in large animals. Further research is needed on pain mechanisms and their phylogenetic bases across farm animal species. ${ }^{13}$

\section{Materials and methods}

In order to assess published data on pain in large animals, we conducted a literature search on PubMed by using the keywords: "animal model sheep and pain", "animal model horse and pain", "animal model cattle and pain", "animal model cow and pain", "animal model pony and pain", and "animal model pig and pain". We searched a full range of articles that explain how the authors assessed pain in these animal models.

For "pig" we conducted a further search for clinical trials only, with the words "pig and pain" and "pig and castration". This additional search for "pig" reflected the importance of this animal model in the scientific community, despite the fact that other species are also used. We searched "pig and castration" because castration is one of the most common operations to cause pain in this animal, so analyzing the evaluation of pain in this context could help us assess pain in pigs more effectively.

To summarize the results of the literature search, we used tables with four columns containing the following information: the first author as reported in the article, the publication year, the animal model used, and a brief description of how pain was evaluated.

We listed the articles in the table in order of publication year, from newest to oldest. For each species, we also grouped together the articles which evaluated pain in similar ways, and in the description, we ordered the methods used from most frequent to least frequent.

\section{Large animal studies - the current situation}

There are a number of reasons why rodent models have dominated the study of pain mechanisms: they cost less, are easier to manage ethically, and there is a large historical database of previous research with which authors can compare new findings. However, large animal models may predict human biology and pharmacology more accurately for a number of pain conditions. Validated pain models in these animals could facilitate the development of new and efficient analgesic drugs with few side effects, which could also be used in humans. In fact, the phylogenetic proximity of humans and large animals plays a key role for several reasons: ${ }^{14}$ 1) species-specific variations in sequence patterns which result in different affinity or potency of the target; 2 ) they share a greater sequence homology than small animals and humans; 3 ) they experience different evolutionary pressure and therefore express pain in different ways; and 4) they have a different drug metabolism (large animals better predict human metabolism). ${ }^{15}$ Unfortunately, a universal method for identifying and recording pain objectively in large animal models has not yet been developed.

In studies involving cattle, locomotor function is used as the main indicator for pain. Bruijnis et al used a fivepoint scale, in which scores 1 (discomfort) and 2 (severe discomfort) represented a subclinical disorder visible on close inspection, where scores 3 (pain), 4 (severe pain), and 5 (very severe pain) represented a clinical disorder which causes lameness. ${ }^{16,17}$ O'Driscoll et al used a locomotion score which considered four characteristics (spine curvature, tracking, head carriage, and abduction/adduction), each of which was evaluated on a five-point scale, from less severe to very severe. ${ }^{18}$

Rajkondawar et al compared a gait score (GS), a fivepoint score from "sound" to "severely lame", and a lesions score (LS), in which lesion descriptions (such as "sole ulcer", "interdigital dermatitis", "puncture wound of the sole", and "hemorrhage") were associated with a score. This led to a better descriptor of lameness in cows. ${ }^{19}$ The authors found that LS was a better descriptor of lameness than GS. Thoefner et al, in a study on heifers, considered lameness an indicator of pain, as well as other clinical signs, such as claw inflammation (warmth and increased pulsation), cardiovascular function, and gastrointestinal status. ${ }^{20}$

Newby et al, in a study for evaluating the effects of a label dose of ketoprofen after left displaced abomasums surgery in dairy cattle, used physiological (respiratory rate, heart rate, rumen motility, and rectal temperature) and behavioral 
(bright/quiet, alert, responsive, depressed, unresponsive) indicators of pain, ${ }^{21}$ whereas Saeed et al, after median sternotomy in calves, evaluated pain only by indirect signs such as heart rate, respiratory rate, and the animal's ability to change posture. ${ }^{22}$

Finally, Coetzee et al, in a study to evaluate plasma concentration of substance $\mathrm{P}$ and cortisol after castration or simulated castration in calves, also considered behavioral changes such as vocalization (scored on a scale of 0 (no vocalization) to 3 (continuous vocalization), and attitude or temperament, scored on a scale of 0 (unchanged from premanipulation behavior) to 3 (violent escape behavior) (Table 1). ${ }^{23}$

Pippi et al analyzed three kinds of pain (superficial, deep, and visceral) to test analgesic drugs in ponies. The test for superficial pain used a heat source on a skin area, the test for deep pain used a current stimulus through a heating device on the surface of the radius, and the visceral test used a pressure stimulus through a rubber balloon into the cecum. In all the cases, the animal's reaction was movement away from the source in the superficial and deep tests, and a strong movement in the visceral test. This movement was recorded using an accelerometer. ${ }^{24}$ Boatwright et al, in a study comparing two drugs for analgesia in a model of abdominal pain in ponies, used a cumulative pain score, a numerical ranking based only on physical criteria (kicking, pawing, head movement) with a score ranging from 0 (no pain) to 12 (maximum pain). ${ }^{25}$ Clinical signs of colic in ponies were used by Roelvink et al to evaluate pain in a comparative study of two analgesic and spasmolytic drugs. These signs (head shaking, kicking the abdomen, flehmen,

Table I Articles analyzing pain evaluation in cattle

\begin{tabular}{|c|c|c|c|}
\hline First author & $\begin{array}{l}\text { Publication } \\
\text { year }\end{array}$ & $\begin{array}{l}\text { Animal } \\
\text { model }\end{array}$ & $\begin{array}{l}\text { Pain evaluation } \\
\text { in cattle }\end{array}$ \\
\hline Newby et $\mathrm{al}^{23}$ & 2013 & Cows & $\begin{array}{l}\text { Behavioral assessment } \\
\text { with an ethogram }\end{array}$ \\
\hline Bruijnis et al ${ }^{19}$ & 2012 & Cattle & Locomotion score \\
\hline $\begin{array}{l}\text { O'Driscoll } \\
\text { et } \mathrm{al}^{20}\end{array}$ & 2009 & Cows & Locomotion score \\
\hline Saeed et $\mathrm{al}^{24}$ & 2008 & Calves & $\begin{array}{l}\mathrm{RR}, \mathrm{HR} \text {, ability to } \\
\text { change posture }\end{array}$ \\
\hline $\begin{array}{l}\text { Coetzee } \\
\text { et } \mathrm{al}^{25}\end{array}$ & 2008 & Calves & $\begin{array}{l}\text { Vocalization and change } \\
\text { in attitude or temperament }\end{array}$ \\
\hline $\begin{array}{l}\text { Rajkondawar } \\
\text { et } \mathrm{al}^{21}\end{array}$ & 2006 & Cows & $\begin{array}{l}\text { Reaction after claw } \\
\text { compression and gait score }\end{array}$ \\
\hline $\begin{array}{l}\text { Thoefner } \\
\text { et } \mathrm{al}^{22}\end{array}$ & 2004 & Heifers & $\begin{array}{l}\text { Evaluation of lameness, } \\
\text { signs of claw inflammation, } \\
\text { cardiovascular function, } \\
\text { gastrointestinal function }\end{array}$ \\
\hline
\end{tabular}

Abbreviations: $H R$, heart rate; $R R$, respiratory rate. stretching, pawing the ground and looking at the abdomen, yawning, restlessness, and leaning against the stocks) were evaluated before and after the administration of the drugs. ${ }^{26}$ Fikes et al compared lidocaine and xylazina as epidural analgesics in ponies; to evaluate pain, they observed the reaction to a pin prick adjacent to the anus. Movements, such as attempts to kick or turn the head towards the stimulus site, were considered positive signs of pain. ${ }^{27}$ Epidural analgesia in ponies with carpal synovitis was reported by Freitas et al. Pain was assessed mainly through a lameness score, where 0 signified absence of visible lameness and 4 indicated severe lameness. Clinical signs such as heart rate, systolic arterial pressure, respiratory rate, body temperature, and intestinal motility were also evaluated during the experiment (Table 2). ${ }^{28}$

In sheep, pain has largely been evaluated on the basis of escape-avoidance responses to different noxious stimuli. Dolan et al assessed withdrawal responses after formalin injection (into interdigital space) and mechanical stimulation with a pneumatic device. ${ }^{29}$ Wilkes et al used a stiff von Frey filament tip connected to an anesthesiometer on the hind limb of the animal, exerting increasing pressure until it elicited a withdrawal response. ${ }^{30}$ Stubsjøen et al inflated a tourniquet to a pressure of $300 \mathrm{mmHg}$ (or until sheep showed signs of aversion) and Ong et al used four different electrical stimuli to produce a response. ${ }^{31,32}$ Mather et al measured the pain threshold with a pneumo-mechanical pressure device on the animal's foreleg. ${ }^{33}$

Some authors have used clinical signs and measurements (heart rate, blood pressure, eye temperature, rectal body temperature, electromyography), behavioral measures (appetite,

Table 2 Articles analyzing pain evaluation in ponies

\begin{tabular}{|c|c|c|c|}
\hline $\begin{array}{l}\text { First } \\
\text { author }\end{array}$ & $\begin{array}{l}\text { Publication } \\
\text { year }\end{array}$ & $\begin{array}{l}\text { Animal } \\
\text { model }\end{array}$ & Pain evaluation in ponies \\
\hline $\begin{array}{l}\text { Freitas } \\
\text { et } \mathrm{al}^{30}\end{array}$ & 2011 & Ponies & $\begin{array}{l}\text { Lameness, HR, SAP, RR, T, } \\
\text { intestinal motility }\end{array}$ \\
\hline $\begin{array}{l}\text { Boatwright } \\
\text { et } \mathrm{al}^{27}\end{array}$ & 1996 & Ponies & $\begin{array}{l}\text { CPS - kicking, pawing, } \\
\text { head movement }\end{array}$ \\
\hline $\begin{array}{l}\text { Roelvink } \\
\text { et } \mathrm{al}^{28}\end{array}$ & 1991 & Ponies & $\begin{array}{l}\text { Head-shaking, flehmen, yawning, } \\
\text { stretching, restlessness, leaning } \\
\text { against the stocks, looking } \\
\text { at the abdomen, kicking } \\
\text { the abdomen and pawing } \\
\text { the ground }\end{array}$ \\
\hline $\begin{array}{l}\text { Fikes } \\
\text { et } \mathrm{al}^{29}\end{array}$ & 1989 & Ponies & $\begin{array}{l}\text { Movement, attempts to kick, } \\
\text { turning the head towards the } \\
\text { site of a pin prick }\end{array}$ \\
\hline $\begin{array}{l}\text { Pippi } \\
\text { et } \mathrm{al}^{26}\end{array}$ & 1978 & Ponies & $\begin{array}{l}\text { Superficial, deep, and visceral } \\
\text { pain tests }\end{array}$ \\
\hline
\end{tabular}

Abbreviations: $C P S$, composite pain scale; $H R$, heart rate; $R R$, respiration rate; SAP, systolic arterial pressure; $\mathrm{T}$, body temperature. 
vocalization, lip-licking, teeth-gnawing, ear posture, reaction to the environment, social isolation, feeding behavior), and motor function (abnormalities in gait, righting reflex, limping) as direct and indirect signs of pain. ${ }^{34-39}$ Welsh et al compared a visual analog scale (VAS) and a numerical rating scale (NRS), developed by two veterinarians, to assess lameness in sheep. They found that, although the NRS and VAS are both repeatable and reproducible but not interchangeable, the VAS is intrinsically more sensitive. ${ }^{40}$ An evaluation of electroencephalography (EEG) changes in young lambs before, during, and after seven treatments (tail-docking, castration, sham-shearing, formalin injection, mulesing, ear-tagging, handling) was reported by Jongman et al, ${ }^{41}$ and showed a good correlation between EEG and painful procedure (Table 3 ).

Table 3 Articles analyzing pain evaluation in sheep

\begin{tabular}{|c|c|c|c|}
\hline $\begin{array}{l}\text { First } \\
\text { author }\end{array}$ & $\begin{array}{l}\text { Publication } \\
\text { year }\end{array}$ & $\begin{array}{l}\text { Animal } \\
\text { model }\end{array}$ & Pain evaluation in sheep \\
\hline $\begin{array}{l}\text { Yong } \\
\text { et al }{ }^{39}\end{array}$ & 2014 & Sheep & $\begin{array}{l}\text { Gait abnormalities, teeth-gnawing, } \\
\text { social isolation }\end{array}$ \\
\hline $\begin{array}{l}\text { Wilkes } \\
\text { et al }{ }^{32}\end{array}$ & 2012 & Sheep & Hind limb withdrawal thresholds \\
\hline $\begin{array}{l}\text { Hee } \\
\text { et } \mathrm{al}^{40}\end{array}$ & 2011 & Sheep & $\begin{array}{l}\text { Animal alertness, movement, } \\
\text { flock behavior, feeding behavior, } \\
\text { and respiratory rate }\end{array}$ \\
\hline $\begin{array}{l}\text { Dolan } \\
\text { et } \mathrm{al}^{31}\end{array}$ & 2011 & Sheep & $\begin{array}{l}\text { Withdrawal response to mechanical } \\
\text { stimulation; time spent not bearing } \\
\text { weight or flinching }\end{array}$ \\
\hline $\begin{array}{l}\text { Stubsjøen } \\
\text { et } \mathrm{al}^{33}\end{array}$ & 2010 & Sheep & $\begin{array}{l}\text { Lifting the limb after tourniquet } \\
\text { inflation }\end{array}$ \\
\hline $\begin{array}{l}\text { Wegener } \\
\text { et al }{ }^{37}\end{array}$ & 2009 & Sheep & Limping and other signs of pain \\
\hline $\begin{array}{l}\text { Stubsjøen } \\
\text { et } \mathrm{al}^{41}\end{array}$ & 2009 & Sheep & $\begin{array}{l}\text { Eye temperature, heart rate, heart } \\
\text { rate variability, blood pressure, } \\
\text { vocalization, lip-licking, ear posture }\end{array}$ \\
\hline $\begin{array}{l}\text { Houfflin } \\
\text { Debarge } \\
\text { et } \mathrm{al}^{38}\end{array}$ & 2005 & Sheep & $\begin{array}{l}\text { Nociceptive flexion reflex, } \\
\text { neurovegetative response } \\
\text { (mean aortic pressure and fetal } \\
\text { heart rate), EMG }\end{array}$ \\
\hline $\begin{array}{l}\text { Johansen } \\
\text { et } \mathrm{al}^{36}\end{array}$ & 2004 & Sheep & $\begin{array}{l}\text { Appetite, posture, ambulation, } \\
\text { herding activity, reaction to the } \\
\text { environment, and rectal body } \\
\text { temperature } \\
\text { Behavior and motor function } \\
\text { recorded on a four-grade scale }\end{array}$ \\
\hline $\begin{array}{l}\text { Jongman } \\
\text { et a }{ }^{43}\end{array}$ & 2000 & Sheep & EEG changes \\
\hline $\begin{array}{l}\text { Mather } \\
\text { et } \mathrm{al}^{35}\end{array}$ & 2000 & Sheep & Foreleg lift escape response \\
\hline $\begin{array}{l}\text { Ong } \\
\text { et } \mathrm{al}^{34}\end{array}$ & 1997 & Sheep & $\begin{array}{l}\text { Escape-avoidance responses to the } \\
\text { electrical stimuli }\end{array}$ \\
\hline $\begin{array}{l}\text { Welsh } \\
\text { et } \mathrm{al}^{42}\end{array}$ & 1993 & Sheep & VAS and NRS score \\
\hline
\end{tabular}

Abbreviations: EEG, electroencephalography; EMG, electromyography; NRS, numerical rating scale; VAS, visual analog scale.
In studies involving horses as animal models, lameness is considered the main indicator of pain. Buchner et al used kinematic patterns of head and trunk, as well as the body centre of mass, to evaluate adaptations in movement during experimental lameness. ${ }^{42,43}$ This indicator was applied to assess repair and the evolution of pain after removing calcified cartilage. ${ }^{44}$ Other authors used a lameness score associated with other signs. Collier et al, for example, analyzed whether the surgical site was hot, painful, or swollen, ${ }^{45}$ and an increase in heart rate has also been used as a good indicator of the severity of lameness. ${ }^{46-49}$ Cornelissen et al, using a five-point scale of lameness, considered indirect clinical and behavioral signs of pain such as heart and respiratory rate, rectal temperature, demeanor, appetite, and circumference and distension of the fetlocks; they also noted changes in local temperature by palpation. ${ }^{50}$ Cayzer et al measured responses to pain through flexion tests and joint palpation, and noted the degree of swelling, scoring each indicator on a five-point scale. ${ }^{51}$ Some authors have detected pain by monitoring mainly behavioral responses. Bussières et al, for example, used a composite pain scale (CPS) with multifactorial numerical rating, which was also used by Van Loon et al. ${ }^{52,53}$ The CPS considers physiological data (heart rate, respiratory rate, digestive sounds, rectal temperature), response to treatment (response to palpation of the painful area and interactive behavior), and behavior (sweating, appearance, posture, kicking at abdomen, pawing on the floor, head movement, appetite). In the authors' opinion, these indicators are the most effective in identifying orthopedic pain. Scantlebury et al studied the incidence of recurrent colic in horses and the risk factors involved, using specific indicators of colic as signs of pain, including pawing, violent rolling, lying still, getting up and down, kicking belly, vocalization, rolling eyes, rapid breathing, and irritability. Other clinical signs, such as heart and respiratory rate, temperature, and borborygmi were considered. ${ }^{54}$ Clinical observations such as resting, respiratory rate, rectal temperature, carpal flexion angle, carpal circumference, carpal hyperthermia, and signs of carpal pain were scored on a scale from 0 (no warmth/signs of pain) to 2 (marked warmth/signs of pain). ${ }^{55}$ Miller et al considered indirect signs of pain, and evaluated the quality of analgesia during anesthesia in horses, using EEG, electrocardiography, heart rate, and blood pressure. The authors found that associating EEG and standard clinical parameters led to a better understanding of anesthetic management. Haussler et al assessed pain in horses with a pressure algometer, looking for avoidance reactions such as skin-twitching, local muscle fasciculation, lifting the thoracic 
limb, or stepping away from the pressure source. ${ }^{56,57}$ Finally, Fureix et al hypothesized that chronic pain (for the presence of vertebral problems) in horses is associated with increased aggression towards humans. ${ }^{58}$ The authors found that chronic pain may behave similarly to acute pain, and therefore, it is important to include chronic pain as an influential factor in interpersonal relations and aggressive behavior (Table 4).

\section{Focusing on pigs}

In studies on pain, pigs seem to be the most suitable animal model. They share a number of anatomical and physiological characteristics with man. Moreover, their median body size facilitates the collection of samples such as biopsies, body fluids, and blood samples, which can be managed conveniently in standard facilities. Moreover, pigs are omnivorous, and

Table 4 Articles analyzing pain evaluation in horses

\begin{tabular}{|c|c|c|c|}
\hline $\begin{array}{l}\text { First } \\
\text { author }\end{array}$ & $\begin{array}{l}\text { Publication } \\
\text { year }\end{array}$ & $\begin{array}{l}\text { Animal } \\
\text { model }\end{array}$ & Pain evaluation in horses \\
\hline $\begin{array}{l}\text { van Loon } \\
\text { et } \mathrm{al}^{55}\end{array}$ & 2012 & Horses & $\begin{array}{l}\text { CPS with physiological } \\
\text { response to treatment and } \\
\text { behavioral data }\end{array}$ \\
\hline $\begin{array}{l}\text { Foreman } \\
\text { et } \mathrm{al}^{50}\end{array}$ & 2012 & Horses & Lameness scale and HR \\
\hline $\begin{array}{l}\text { Cayzer } \\
\text { et } \mathrm{al}^{53}\end{array}$ & 2012 & Horses & $\begin{array}{l}\text { Flexion test, response to pain } \\
\text { in palpation of joints, swelling } \\
\text { flexion test, swelling }\end{array}$ \\
\hline $\begin{array}{l}\text { Scantlebury } \\
\text { et } \mathrm{al}^{56}\end{array}$ & 2011 & Horses & $\begin{array}{l}\text { Signs of colic and clinical } \\
\text { signs }\end{array}$ \\
\hline $\begin{array}{l}\text { Foreman } \\
\text { et } \mathrm{al}^{48}\end{array}$ & 2011 & Horses & Lameness score and HR \\
\hline $\begin{array}{l}\text { Fureix } \\
\text { et } \mathrm{al}^{60}\end{array}$ & 2010 & Horses & $\begin{array}{l}\text { Increased aggressiveness } \\
\text { towards humans }\end{array}$ \\
\hline $\begin{array}{l}\text { Foreman } \\
\text { et } \mathrm{al}^{49}\end{array}$ & 2008 & Horses & Lameness score and HR \\
\hline $\begin{array}{l}\text { Bussières } \\
\text { et } \mathrm{al}^{54}\end{array}$ & 2008 & Horses & $\begin{array}{l}\text { CPS with physiological } \\
\text { response to treatment and } \\
\text { behavioral data }\end{array}$ \\
\hline $\begin{array}{l}\text { Haussler } \\
\text { et al }{ }^{59}\end{array}$ & 2007 & Horses & Avoidance reactions \\
\hline $\begin{array}{l}\text { Frisbie } \\
\text { et } \mathrm{al}^{46}\end{array}$ & 2006 & Horses & Lameness \\
\hline Seino et $\mathrm{al}^{51}$ & 2003 & Horses & Lameness score and HR \\
\hline $\begin{array}{l}\text { Buchner } \\
\text { et } \mathrm{al}^{45}\end{array}$ & 2001 & Horses & Lameness \\
\hline $\begin{array}{l}\text { Cornelissen } \\
\text { et } \mathrm{al}^{52}\end{array}$ & 1998 & Horses & $\begin{array}{l}\text { Lameness scale and local } \\
\text { signs }\end{array}$ \\
\hline $\begin{array}{l}\text { Hamm } \\
\text { et } \mathrm{al}^{57}\end{array}$ & 1997 & Horses & $\begin{array}{l}\text { Subjective signs of carpal pain } \\
\text { and clinical signs }\end{array}$ \\
\hline $\begin{array}{l}\text { Buchner } \\
\text { et } \mathrm{al}^{44}\end{array}$ & 1996 & Horses & Lameness score \\
\hline Miller et $\mathrm{al}^{58}$ & 1995 & Horses & EEG, EMG HR, BP \\
\hline $\begin{array}{l}\text { Collier } \\
\text { et } \mathrm{al}^{47}\end{array}$ & 1985 & Horses & $\begin{array}{l}\text { Lameness score and clinical } \\
\text { signs (heat and swelling) }\end{array}$ \\
\hline
\end{tabular}

Abbreviations: BP, blood pressure; CPS, composite pain scale; ECG, EMG, electromyography; EEG, electroencephalography; HR, heart rate. anatomically, have a similar digestive apparatus to humans. The skin of pigs is similar to human skin in that it has little hair, and the pigmentation changes in different breeds. ${ }^{59}$ The similarities between the skin of pigs and humans has been demonstrated in a number of studies, particularly when the animal is on average $12 \pm 4$ weeks of age and the body weight is $20-27 \mathrm{~kg} .{ }^{60}$ Number, size, distribution, and communications of vessels in dermal porcine skin are similar to those in human skin, ${ }^{61}$ as are tissue turnover time and keratinous proteins in the epidermis. ${ }^{62}$ Transmission electron microscopy shows that the epidermal-dermal junctions in pigs and humans are similar, as well as immunoreactivity in the peptide nerve fibers, for example calcitonin gene related peptide, vasoactive intestinal polypeptide (VIP), and substance $\mathrm{P}^{63,64}$ Changes in distribution and axonal excitability of nociceptive and non-nociceptive fiber classes are also similar in humans and pigs, which means that this animal model can be used to study the modulation of excitability in these C-fiber classes. ${ }^{65}$

Unfortunately, pain in pigs can only be estimated by responses to nociceptive stimuli and none of these are ideal. Any reactions which are monitored are similar to other animal models in that they are almost always motor responses ranging from spinal reflexes to complex behaviors. Motor responses, however, are not the only ones analyzed. In fact, Kluivers-Poodt et al, who studied the effect of pain relief in piglets, used vocalization as an indicator. ${ }^{66}$ Using the common classification system described by Weary et al, ${ }^{67}$ they divided the calls produced by piglets into "high calls" $(\geq 1,000 \mathrm{~Hz})$ and "low calls" $(<1,000 \mathrm{~Hz})$, and these variations may reflect not only gross quantitative differences, but also the intensity and nature of the pain. The calls are registered to provide a record of their characteristics, using measures such as temporal parameters (eg, call rate and duration), waveform parameters (ie, peak-to-peak), and spectrum-based parameters (including peak amplitude and frequency, main frequency, and band width).

Other authors have used vocalization in association with other behaviors, but have evaluated quantitative characteristics, rather than qualitative ones as described above. Walker et al assessed the reaction of piglets after castration by monitoring the presence and degree of movements, and the presence or absence of vocalization. ${ }^{68}$ Reyes et al modified a method used by Firth and Morton, which considers behavioral parameters such as vocalization, lameness, aggression, restlessness, posture, isolation, appearance, sling time, agitation, and posture. ${ }^{69-71}$ Possible scores ranged from 10 (no pain) to 35 (maximum pain). Other clinical parameters were 
heart and respiratory rate, blood pressure, and temperature. Lupu et al analyzed the response after a pinprick test - the usual response involved vocalization and/or withdrawal of the ipsilateral forelimb. On the other hand, Navarro et al, in addition to measuring withdrawal responses and vocalization after a mechanical stimulus, analyzed motor function, muscle hypertonia and hyperreflexia, anal sensation, and the presence of allodynia to study a chronic spinal compression model in minipigs. ${ }^{72,73}$ Sutherland et al, in their study on reactions in pigs after castration with or without anesthesia, analyzed behavior such as lying down, nursing, sitting, standing, and walking. In terms of behavior indicating pain, the authors analyzed sitting, huddling, scooting, and stress vocalization, with an automatic system for monitoring stress calls. ${ }^{74}$ Murison et al, in their study on pain behavior after laryngeal transplant, used a combination of locomotion scores to assess pain (the willingness of the pig to lie down, to stretch its neck and to approach its food, or how it moved), wound palpation (gently increasing pressure until the animal responded by turning away or grunting, for example), and other behavior (grunting, willingness to play with carers, appetite, or nesting behavior). Numerical scores were used, from 0 (no pain) to 10 (worst pain imaginable). ${ }^{75}$ In a study to evaluate the response to doses of ketoprofen, Mustonen et al examined clinical signs (locomotion, general temperature, respiratory rate, and general behavior) to form a total clinical score. ${ }^{76}$ The same authors used a five-grade lameness scale to measure the efficacy of oral ketoprofen, recording lameness scores before and after the treatments as an index of pain relief. ${ }^{77}$ Friton et al also used lameness as a primary parameter. ${ }^{78}$ In a study to evaluate the safety and efficacy of meloxicam in non-infectious locomotor disorders in pigs, the authors used clinical examination classifications to describe and categorize "lameness at rest" and "lameness while walking", as well as "feed intake" and "behavior". Other authors have analyzed pain indicators in terms of behavior such as inactivity, huddling up, trembling, tail-wagging, scratching, stiffness, sleep spasms, recumbency, coprophagy, aggression, depression, head-pressing, changes in activity, nursing, lying, body movement, muscle-twitching, and withdrawal. ${ }^{79-84}$ These analyses allowed the authors to evaluate pain relief in pigs, distress after surgical procedures (such as castration), and the effects of some analgesics. Finally, some authors have used different methods, such as assessing postoperative analgesia after femoral fracture in pigs using a modified VAS for five different conditions: VAS1, observation; VAS2, contact; VAS3, ambulation; VAS4, vocalization; and VAS5, overall. The VAS chart consisted of a $100 \mathrm{~mm}$ horizontal line, where the left side represented no pain and the right side the highest level of pain. ${ }^{85}$ Haga et al analyzed EEG, mean arterial blood pressure, and pulse rates as indicators of pain in post-castration piglets. The results showed significant differences between animals which had received intrafunicular or intratesticular lidocaine and the control group which had not received it. ${ }^{86}$ Rukwied et al analyzed axon reflex vasodilatation by laser Doppler imaging as an indirect sign of C-fiber activation after irradiating pig skin to create erythema and applying mechanical (with von Frey needles) and thermal stimuli (with increased skin temperature to $45^{\circ} \mathrm{C}$ or $\left.47^{\circ} \mathrm{C}\right) .{ }^{87}$ To measure the concentration of substance $\mathrm{P}$ and VIP involved in the transmission of pain, Cornefjord et al applied an ameroid constrictor at the root of the spinal nerve, and measured the gradual reduction in diameter of tissue samples from the nerve root (cranial to constrictor), and from the dorsal root (ganglion). ${ }^{88}$ The results showed that there was an increase of substance $\mathrm{P}$ but no significant differences in VIP concentration (Table 5).

Reactions analyzed in the studies of all species include: 1) responses organized by centers which are "low" in the hierarchy of the central nervous system (termed "pseudoaffective reflexes") - these include neurovegetative reactions (tachycardia, hyperpnea, arterial hypertension, etc), basic motor responses (contractures, withdrawal, etc), and vocalization; ${ }^{89,90}$ and 2) more complex responses integrated by higher nervous centers, which include conditioned motor responses after a period of learning such as behavioral reaction (escape, avoidance, aggression, etc) or modifications of behavior (social, food, sleep, etc).

However, none of these evaluations are entirely satisfactory. They display a number of weaknesses, some of which are due to the types of stimuli or how they are applied, the plasticity of the animal or the way the data has been measured. Specific protocols will therefore need to be developed to improve estimates of pain in animal models, and in future, in patients who are unable to express their pain verbally, such as infants and comatose or cognitively impaired patients (Table 6). ${ }^{91-93}$

\section{Future pain models in pigs}

When we choose the animal species for a scientific study, it is important to consider the similarity of organs and tissues between the animal and humans. It is not possible, therefore, to make a general statement about animal models. ${ }^{94}$ For example, some experts suggest that non-human primates should be used where there is no alternative, such as in studies involving neuroscience and brain function, or in diseases common to 
Table 5 Articles evaluating pain in pigs

\begin{tabular}{|c|c|c|c|}
\hline First author & Publication year & Animal model & Pain evaluation \\
\hline Royal et $\mathrm{al}^{87}$ & 2013 & Pigs & HR, RR, subjective pain assessment with a modified VAS \\
\hline \multirow[t]{2}{*}{ Di Giminiani et $\mathrm{al}^{85}$} & \multirow[t]{2}{*}{2014} & \multirow[t]{2}{*}{ Pigs } & Body movement, rubbing, muscle twitches \\
\hline & & & Leg movements, lifting the leg, kicking \\
\hline \multirow[t]{2}{*}{ Navarro et $\mathrm{al}^{75}$} & \multirow[t]{2}{*}{2012} & \multirow[t]{2}{*}{ Minipigs } & Withdrawal response to a mechanical stimulus, vocalization, muscle \\
\hline & & & hypertonia and hyperreflexia, anal sensation, and presence of allodynia \\
\hline Mustonen et $\mathrm{al}^{78}$ & 2012 & Pigs & General behavior, RR, locomotion, rectal temperature \\
\hline Janczak et $\mathrm{al}^{86}$ & 2012 & Piglets & Withdrawal response \\
\hline Kluivers-Poodt et $a^{68}$ & 2012 & Piglets & Vocalization \\
\hline Sutherland et $\mathrm{al}^{76}$ & 2012 & Pigs & Scooting, sitting, huddling, vocalization \\
\hline Rault et $\mathrm{al}^{81}$ & 2011 & Piglets & $\begin{array}{l}\text { Tail-wagging, huddling up, trembling, stiffness, lying prostrate, spasms, } \\
\text { scratching, sleep spasms }\end{array}$ \\
\hline Van Beirendonck et $\mathrm{al}^{82}$ & 2011 & Piglets & Huddling up, trembling, spasms, scratching, tail-wagging \\
\hline Mustonen et $\mathrm{al}^{79}$ & 2011 & Sows & Lameness \\
\hline Lupu et $\mathrm{al}^{74}$ & 2010 & Pig & Vocalization and/or withdrawal of the forelimb \\
\hline Murison et $\mathrm{al}^{77}$ & 2009 & Pigs & Wound palpation, behavior, and locomotion scoring \\
\hline Rukwied et a ${ }^{89}$ & 2008 & Pigs & Reflex erythema \\
\hline Carroll et $\mathrm{al}^{84}$ & 2006 & Pigs & Active, lying, sitting, standing, and nursing \\
\hline Haga et $\left.\right|^{88}$ & 2005 & Piglets & EEG, MAP, pulse rate \\
\hline Walker et $\mathrm{al}^{70}$ & 2004 & Piglets & Vocalization and movement \\
\hline Friton et $\mathrm{al}^{80}$ & 2003 & Pigs & Lameness, food intake, behavior \\
\hline Reyes et $\mathrm{al}^{71}$ & 2002 & Piglets & $\begin{array}{l}\text { Lameness, isolation, posture, vocalization, aggression, restlessness, } \\
\text { agitation, and playfulness }\end{array}$ \\
\hline Harvey-Clark et al ${ }^{83}$ & 2000 & Pigs & $\begin{array}{l}\text { Inactivity, recumbency, aggression, depression, head-pressing, } \\
\text { coprophagy, stereotypical chewing, changes in activity }\end{array}$ \\
\hline Cornefjord et $\mathrm{al}^{90}$ & 1995 & Pigs & Increase in substance $P$ \\
\hline
\end{tabular}

Abbreviations: EEG, electroencephalography; HR, heart rate; MAP, mean arterial blood pressure; RR, respiratory rate; VAS, visual analog scale.

man and other primates (HIV/AIDS or tuberculosis). On the other hand, dogs are preferred in the development of antiulcer drugs because of the similarity between the human and canine gastric mucosal membrane. ${ }^{95}$

In terms of pain and its evaluation, it is important to emphasize that each species manifests pain in its own way, according to the behavioral repertoire of the species, and a particular reaction does not necessarily suggest that the animal is experiencing pain. Moreover, no single behavior is a

Table 6 Biological similarities between humans and large animals

I. Phylogenetic proximity:

- Greater sequence homology

- Better prediction of human metabolism

- Less species-specific variations in sequence patterns

- Different evolutionary pressure

2. Median body size

3. Humans and pigs are both omnivorous

4. Similar digestive apparatus with porcine species

5. Similarity with porcine skin:

- Number, size, distribution, and communications of dermal vessels

- Tissue turnover time

- Keratinous proteins in the epidermis

- Epidermal-dermal junctions

6. Immunoreactivity in the peptide nerve fibers

7. Similarities in nociceptive and non-nociceptive fiber classes definite sign of pain, and each reaction must be assessed in context (Committee on Regulatory Issues in Animal Care and Use, 2000). ${ }^{96}$ In fact, vocalization in piglets is not necessarily an indicator of pain. Piglets run a natural risk of being crushed by their mother, and they have developed a low threshold for screaming in order to alert her. Piglets will scream simply if they are picked up, but this does not mean they are feeling any pain. Equally, it is not true to say that piglets never feel pain when they scream. It only means that vocalization, as a single indicator, is not a sensitive parameter of pain.

Conversely, if it is difficult to find an indicator of pain, we can analyze signs of well-being that suggest the absence of pain, such as play (nudging and running, grabbing, biting chains, playful fighting), vocalization (calling the piglet or conversing in a group), strong growth, and good health. ${ }^{97-99}$

Overall, pigs seem to be the most suitable animal model for studying pain. In fact, there are a number of reasons for choosing pigs. Firstly, their similarities with humans in terms of size, anatomy, and genetics make pigs suitable for studies where results can be reproduced in humans. Secondly, pigs are easily managed in the animal facility, which optimizes the conditions for study. Thirdly, the ethics committee is more likely to approve studies involving pigs as opposed to other 
animals such as dogs or primates, and finally, pigs are most frequently used by the scientific community because they are likely the most practical for follow-up studies.

This evidence therefore indicates that pigs represent the best models for studying and assessing postoperative pain in humans.

\section{Conclusion}

It is necessary to identify new methods for evaluating pain (particularly postoperative pain) in large animals, and pigs represent the most suitable model because of their similarities to humans. The aim would be to transfer the results to human patients, to develop better pain evaluation and treatment. This would be especially useful in non-verbal patients to prevent complications in short- and long-term therapies due to incorrect diagnosis on the basis of pain.

Teamwork will be essential in this endeavor: biologists, anesthetists, surgeons, pain therapists, and biomedical engineers will need to work together "from bench to bedside", each contributing their specific skills to the task.

\section{Acknowledgments}

Grant support: Fondazione Banca del Monte di Lombardia; Fondazione IRCCS Policlinico San Matteo-Pavia. We thank Dr Sabrina Bozzini for technical advice.

\section{Disclosure}

The authors report no conflicts of interest in this work.

\section{References}

1. Mogil JS, Davis KD, Derbyshire SW. The necessity of animal models in pain research. Pain. 2010;151(1):12-17.

2. Mogil JS. Animal models of pain: progress and challenges. Nat Rev Neurosci. 2009;10(4):283-294.

3. Rice AS, Cimino-Brown D, Eisenach JC, et al; Preclinical Pain Consortium. Animal models and the prediction of efficacy in clinical trials of analgesic drugs: a critical appraisal and call for uniform reporting standards. Pain. 2008;139(2):243-247.

4. Mogil JS. The genetic mediation of individual differences in sensitivity to pain and its inhibition. Proc Natl Acad Sci U S A. 1999;96(14): 7744-7751.

5. Geranton SM. Targeting epigenetic mechanisms for pain relief. Curr Opin Pharmacol. 2012;12(1):35-41.

6. Patti GJ, Yanes O, Siuzdak G. Innovation: metabolomics: the apogee of the omics trilogy. Nat Rev Mol Cell Biol. 2012;13(4):263-269.

7. Matthies BK, Franklin KB. Formalin pain is expressed in decerebrate rats but not attenuated by morphine. Pain. 1992;51:199-206.

8. Woolf CJ. Long term alterations in excitability of the flexion reflex produced by peripheral tissue injury in the chronic decerebrate rat. Pain. 1984;18:325-343.

9. Kauppila T, Kontinen VK, Pertovaara A. Weight bearing of the limb as a confounding factor in assessment of mechanical allodynia in the rat. Pain. 1998;74:55-59.

10. Franklin KB, Abbott FV. Psychopharmacology. In: Boulton AA, Baker GB, Greenshaw AJ, editors. Neuromethods. Vol 13. Clifton, NJ: Humana; 1989.
11. Guilbaud G, Gautron M, Jazat F, Ratinahirana H, Hassig R, Hauw JJ. Time course of degeneration and regeneration of myelinated nerve fibres following chronic loose ligatures of the rat sciatic nerve: can nerve lesions be linked to the abnormal pain-related behaviours. Pain. 1993;53:147-158.

12. Price DD. Psychological and neural mechanisms of the affective dimension of pain. Science. 2000;288:1769-1772.

13. Guatteo R, Levionnois O, Fournier D, et al. Minimising pain in farm animals: the $3 \mathrm{~S}$ approach - 'Suppress, Substitute, Soothe'. Animal. 2012;6(8):1261-1274.

14. Henze DA, Urban MO. Large animal models for pain therapeutic development. In: Kruger L, Light AR, editors. Translational Pain Research: From Mouse to Man. Boca Raton, FL: CRC Press; 2010. Chapter 17.

15. Ward K, Nagilla R, Jolivette LJ. Comparative evaluation of oral systemic exposure of 56 xenobiotics in rat, dog, monkey and human. Xenobiotica. 2005;35(2):191-210.

16. Jaggi AS, Jain V, Singh N. Animal models of neuropathic pain. Fundam Clin Pharmacol. 2011;25(1):1-28.

17. Blackburn-Munro G. Pain-like behaviours in animals - how human are they? Trends Pharmacol Sci. 2004;25(6):299-305.

18. Le Bars D, Gozariu M, Cadden SW. Animal models of nociception. Pharmacol Rev. 2001;53:597-652.

19. Bruijnis MR, Beerda B, Hogeveen H, Stassen EN. Assessing the welfare impact of foot disorders in dairy cattle by a modeling approach. Animal. 2012;6(6):962-970.

20. O'Driscoll KK, Schutz MM, Lossie C, Eicher SD. The effect of floor surface on dairy cow immune function and locomotion score. J Dairy Sci. 2009;92:4249-4261.

21. Rajkondawar PG, Liu M, Dyer RM, et al. Comparison of models to identify lame cows based on gait and lesion scores, and limb movement variables. J Dairy Sci. 2006;89(11):4267-4275.

22. Thoefner MB, Pollitt CC, van Eps AW, et al. Acute bovine laminitis: a new induction model using alimentary oligofructose overload. J Dairy Sci. 2004;87:2932-2940.

23. Newby NC, Pearl DL, LeBlanc SJ, Leslie KE, von Keyserlingk MA, Duffield TF. The effect of administering ketoprofen on the physiology and behavior of dairy cows following surgery to correct a left displaced abomasums. J Dairy Sci. 2013;96:1511-1520.

24. Saeed D, Zahr R, Shalli S. Median sternotomy approach for chronic bovine experiments. ASAIO J. 2008;54(6):585-588.

25. Coetzee JF, Lubbers BV, Toerber SE, et al. Plasma concentrations of substance $\mathrm{P}$ and cortisol in beef calves after castration or simulated castration. Am J Vet Res. 2008;69(6):751-762.

26. Pippi NL, Lumb WV. Objective tests of analgesic drugs in ponies. Am J Vet Res. 1978;40(8):1082-1086.

27. Boatwright CE, Fubini SL, Grohn YT, Goossens L. A comparison of N-butylscopolammonium-bromide and butorphanol tartrate for analgesia using a balloon model of abdominal pain in ponies. Can J Vet Res. 1996;60:65-68.

28. Roelvink ME, Goossens L, Kalsbeek HC, Wensing T. Analgesic and spasmolytic effects of dipyrone, hyoscine-N-butylbromide and a combination of the two in ponies. Vet Rec. 1991;129:378-380.

29. Fikes LW, Lin HC, Thurmon JC. A preliminary comparison of lidocaine and xylazine as epidural analgesics in ponies. Vet Surg. 1989;18(1): 85-86.

30. Freitas GC, Carregaro AB, Gehrcke MI, et al. Epidural analgesia with morphine or buprenorphine in ponies with lipopolysaccharide (LPS)induced carpal synovitis. Can J Vet Res. 2011;75:141-146.

31. Dolan S, Gunn MD, Crossan C, Nolan AM. Activation of metabotropic glutamate receptor 7 in spinal cord inhibits pain and hyperalgesia in a novel formalin model in sheep. Behav Pharmacol. 2011;22(5-6): 582-588.

32. Wilkes D, Li G, Angeles CF, Patterson JT, Huang LY. A large animal neuropathic pain model in sheep: a strategy for improving the predictability of preclinical models for therapeutic development. J Pain Res. 2012;5:415-424. 
33. Stubsjøen SM, Bohlin J, Skjerve E, Valle PS, Zanella AJ. Applying fractal analysis to heart rate time series of sheep experiencing pain. Physiol Behav. 2010;101:74-80.

34. Ong RM, Morris JP, O'Dwyer JK, Barnett JL, Hemsworth PH, Clarke IJ. Behavioural and EEG changes in sheep in response to painful acute electrical stimuli. Aust Vet J. 1997;75(3):189-193.

35. Mather LE, Cousins MJ, Huang YF, Pryor ME, Barratt SM. Lack of secondary hyperalgesia and central sensitization in an acute sheep model regional anesthesia and pain medicine. Reg Anesth Pain Med. 2000;25(2):174-180.

36. Johansen MJ, Gradert TL, Satterfield WC, et al. Safety of continuous intrathecal midazolam infusion in the sheep model. Anesth Analg. 2004:98:1528-1535.

37. Wegener B, Schrimpf FM, Pietschmann MF, et al. Matrix-guided cartilage regeneration in chondral defects. Biotechnol Appl Biochem. 2009;53:63-70.

38. Houfflin Debarge V, Bresson S, Jaillard S, et al. Development of a new model to investigate the fetal nociceptive pathways. Fetal Diagn Ther 2005;20:415-419.

39. Yong MR, Saifzadeh S, Askin GN, Labrom RD, Hutmacher DW, Adam CJ. Establishment and characterization of an open minithoracotomy surgical approach to an ovine thoracic spine fusion model. Tissue Eng Part C Methods. 2014;20(1):19-27.

40. Hee CK, Dines JS, Dines DM, et al. Augmentation of a rotator cuff suture repair using rhPDGF-BB and a type I bovine collagen matrix in an ovine model. Am J Sports Med. 2011;39:1630-1639.

41. Stubsjøen SM, Flø AS, Moe RO, et al. Exploring non-invasive methods to assess pain in sheep. Physiol Behav. 2009;98:640-648.

42. Welsh EM, Gettinby G, Nolan AM. Comparison of a visual analogue scale and a numerical rating scale for assessment of lameness, using sheep as a model. Am J Vet Res. 1993;54(6):976-983.

43. Jongman EC, Morris JP, Barnett JL, Hemsworth PH. EEG changes in 4-week-old lambs in response to castration, tail docking and mulesing. Aust Vet J. 2000;78(5):339-343.

44. Buchner HH, Savelberg HH, Schamhardt HC, Barneveld A. Head and trunk movement adaptations in horses with experimentally induced fore- or hindlimb lameness. Equine Vet J. 1996;28(1):71-76.

45. Buchner HH, Obermüller S, Scheidl M. Body centre of mass movement in the lame horse. Equine Vet J Suppl. 2001;33:122-127.

46. Frisbie DD, Morisset S, Ho CP, Rodkey WG, Steadman JR, McIlwraith CW. Effects of calcified cartilage on healing of chondral defects treated with microfracture in horses. Am J Sports Med. 2006;34(11):1824-1831

47. Collier MA, Brighton CT, Norrdin R, Twardock AR, Rendano VT. Direct current stimulation of bone production in the horse: Preliminary study with a "gap healing" model. Am J Vet Res. 1985;46(3):610-621.

48. Foreman JH, Ruemmler R. Phenylbutazone and flunixin meglumine used singly or in combination in experimental lameness in horses. Equine Vet J Suppl. 2011;40:12-17.

49. Foreman JH, Barange A, Lawrence LM, Hungerford LL. Effects of single-dose intravenous phenylbutazone on experimentally induced, reversible lameness in the horse. J Vet Pharmacol Ther. 2008;31(1): 39-44.

50. Foreman JH, Bergstrom BE, Golden KS, et al. Dose titration of the clinical efficacy of intravenously administered flunixin meglumine in a reversible model of equine foot lameness. Equine Vet J Suppl. 2012;(43): $17-20$.

51. Seino KK, Foreman JH, Greene SA, Goetz TE, Benson GJ. Effects of topical perineural capsaicin in a reversible model of equine foot lameness. J Vet Intern Med. 2003;17(4):563-566.

52. Cornelissen BP, Rijkenhuizen AB, van den Hoogen BM, Rutten VP, Barneveld A. Experimental model of synovitis/capsulitis in the equine metacarpophalangeal joint. Am J Vet Res. 1998;59(8):978-985.

53. Cayzer J, Hedderley D, Gray S. A randomised, double-blinded, placebocontrolled study on the efficacy of a unique extract of green-lipped mussel (Perna canaliculus) in horses with chronic fetlock lameness attributed to osteoarthritis. Equine Vet J. 2012;44(4):393-398.
54. Bussières G, Jacques C, Lainay $\mathrm{O}$, et al. Development of a composite orthopaedic pain scale in horses. Res Vet Sci. 2008;85(2):294-306.

55. van Loon JP, Menke ES, L'ami JJ, Jonckheer-Sheehy VS, Back W, René van Weeren P. Analgesic and anti-hyperalgesic effects of epidural morphine in an equine LPS-induced acute synovitis model. Vet $J$. 2012;193(2):464-470.

56. Scantlebury CE, Archer DC, Proudman CJ, Pinchbeck GL. Recurrent colic in the horse: incidence and risk factors for recurrence in the general practice population. Equine Vet J Suppl. 2011;(39):81-88.

57. Hamm D, Turchi P, Johnson JC, Lockwood PW, Thompson KC, Katz T Determination of an effective dose of eltenac and its camparison with that of flunixin meglumine in horses after experimentally induced carpitis. Am J Vet Res. 1997;58(3):298-302.

58. Miller SM, Short CE, Ekström PM. Quantitative electroencephalographic evaluation to determine the quality of analgesia during anesthesia of horses for arthroscopic surgery. Am J Vet Res. 1995;56(3):374-379.

59. Haussler KK, Hill AE, Frisbie DD, McIlwraith CW. Determination and use of mechanical nociceptive thresholds of the thoracic limb to assess pain associated with induced osteoarthritis of the middle carpal joint in horses. Am J Vet Res. 2007;68(11):1167-1176.

60. Fureix C, Menguy H, Hausberger M. Partners with bad temper: reject or cure? A study of chronic pain and aggression in horses. PLoS One. 2010;5(8):e12434

61. Simon GA, Maibach HI. The pig as an experimental animal model of percutaneous permeation in man: qualitative and quantitative observations - an overview. Skin Pharmacol Appl Skin Physiol. 2000;13(5):229-234.

62. Veiro JA, Cummins PG. Imaging of skin epidermis from various origins using confocal laser scanning microscopy. Dermatology. 1994;189(1): $16-22$.

63. Moritz AR, Henriques FC. Studies of thermal injury. II. The relative importance of time and surface temperature in the causation of cutaneous burns. Am J Pathol. 1947;23:695-720.

64. Weinstein GD. Comparison of turnover time and of keratinous protein fractions in swine and human epidermis. In: Bustad LK, McClellan RO, editors. Swine in Biomedical Research. Seattle, WA: Frayn Printing Co; 1966:287-297.

65. Monteiro-Riviere NA. Ultrastructure evaluation of the porcine integument. In Tumbleson ME, editor. Swine in Biomedical Research. Vol 1. New York: Plenum Press; 1986:641-655.

66. Karanth SS, Springall DR, Kuhn DM, Levene MM, Polak JM. An immunocytochemical study of cutaneous innervation and the distribution of neuropeptides and protein gene product 9.5 in man and commonly employed laboratory animals. Am J Anat. 1991;191(4):369-383.

67. Obreja O, Schmelz M. Single-fiber recordings of unmyelinated afferents in pig. Neurosci Lett. 2010;470(3):175-179.

68. Kluivers-Poodt M, Houx BB, Robben SR, Koop G, Lambooij E, Hellebrekers LJ. Effects of a local anaesthetic and NSAID in castration of piglets, on the acute pain responses, growth and mortality. Animal. 2012;6(9):1469-1475.

69. Weary DM, Braithwaite LA, Fraser D. Vocal response to pain in piglets. Appl Animal Behav Sci. 1998;56:161-172.

70. Walker B, Jäggin N, Doherr M, Schatzmann U. Inhalation anaesthesia for castration of newborn piglets: experiences with isoflurane and isoflurane/NO. J Vet Med A Physiol Pathol Clin Med. 2004;51(3):150-154.

71. Reyes L, Tinworth KD, Li KM, Yau DF, Waters KA. Observer-blinded comparison of two nonopioid analgesics for postoperative pain in piglets. Pharmacol Biochem Behav. 2002;73(3):521-528.

72. Firth AM, Haldane SL. Development of a scale to evaluate postoperative pain in dogs. J Am Vet Med Assoc. 1999;214(5):651-659.

73. Morton DB, Griffiths PH. Guidelines on the recognition of pain, distress and discomfort in experimental animals and an hypothesis for assessment. Vet Rec. 1985;116:431-436.

74. Lupu CM, Kiehl TR, Chan VW, El-Beheiry H, Madden M, Brull R. Nerve expansion seen on ultrasound predicts histologic but not functional nerve injury after intraneural injection in pigs. Reg Anesth Pain Med. 2010;35(2):132-139. 
75. Navarro R, Juhas S, Keshavarzi S, et al. Chronic spinal compression model in minipigs: a systematic behavioral, qualitative and quantitative neuropathological study. J Neurotrauma. 2012;29(3):499-513.

76. Sutherland MA, Davis BL, Brooks TA, Coetzee JF. The physiological and behavioral response of pigs castrated with and without anesthesia or analgesia. J Anim Sci. 2012;90(7):2211-2221.

77. Murison PJ, Jones A, Mitchard L, Burt R, Birchall MA. Development of perioperative care for pigs undergoing laryngeal transplantation: a case series. Lab Anim. 2009;43(4):338-343.

78. Mustonen K, Banting A, Raekallio M, Heinonen M, Peltoniemi OA, Vainio O. Dose-response investigation of oral ketoprofen in pigs challenged with Escherichia coli endotoxin. Vet Rec. 2012;171(3):70.

79. Mustonen K, Ala-Kurikka E, Orro T, et al. Oral ketoprofen is effective in the treatment of non-infectious lameness in sows. Vet J. 2011;190(1): 55-59.

80. Friton GM, Philipp H, Schneider T, Kleemann R. Investigation on the clinical efficacy and safety of meloxicam (Metacam) in the treatment of non-infectious locomotor disorders in pigs. Berl Munch Tierarztl Wochenschr. 2003;116(9-10):421-426.

81. Rault JL, Lay DC Jr. Nitrous oxide by itself is insufficient to relieve pain due to castration in piglets. J Anim Sci. 2011;89(10):3318-3325.

82. Van Beirendonck S, Driessen B, Verbeke G, Geers R. Behavior of piglets after castration with or without carbon dioxide anesthesia. JAnim Sci. 2011;89(10):3310-3317.

83. Harvey-Clark CJ, Gilespie K, Riggs KW. Transdermal fentanyl compared with parenteral buprenorphine in post-surgical pain in swine: a case study. Lab Anim. 2000;34(4):386-398.

84. Carroll JA, Berg EL, Strauch TA, Roberts MP, Kattesh HG. Hormonal profiles, behavioral responses, and short-term growth performance after castration of pigs at three, six, nine, or twelve days of age. J Anim Sci. 2006;84(5):1271-1278.

85. Di Giminiani P, Petersen LJ, Herskin MS. Characterization of nociceptive behavioural responses in the awake pig following UV-B-induced inflammation. Eur J Pain. 2014;18(1):20-28.

86. Janczak AM, Ranheim B, Fosse TK, et al. Factors affecting mechanical (nociceptive) thresholds in piglets. Vet Anaesth Analg. 2012;39(6):628-635.

87. Royal JM, Settle TL, Bodo M, et al. Assessment of postoperative analgesia after application of ultrasound-guided regional anesthesia for surgery in a swine femoral fracture model. J Am Assoc Lab Anim Sci. 2013;52(3):265-276.
88. Haga HA, Ranheim B. Castration of piglets: the analgesic effects of intratesticular and intrafunicular lidocaine injection. Vet Anaesth Analg. 2005;32(1):1-9.

89. Rukwied R, Dusch M, Schley M, Forsch E, Schmelz M. Nociceptor sensitization to mechanical and thermal stimuli in pig skin in vivo. Eur J Pain. 2008;12(2):242-250.

90. Cornefjord M, Olmarker K, Farley DB, Weinstein JN, Rydevik B. Neuropeptide changes in compressed spinal nerve roots. Spine (Phila Pa 1976). 1995;20(6):670-673.

91. Woodworth RS, Sherrington CS. A pseudoaffective reflex and its spinal path. J Physiol. 1904;31(3-4):234-243.

92. Sherrington CS. The Integrative Action of the Nervous System. New York: C Scribner's Sons; 1906.

93. Loewenstein DA, Ownby R, Schram L, Acevedo A, Rubert M, Argüelles T. An evaluation of the NINCDS-ADRDA neuropsychological criteria for the assessment of Alzheimer's disease: a confirmatory factor analysis of single versus multi-factor models. J Clin Exp Neuropsychol. 2001;23(3):274-284.

94. Fuchs-Lacelle S, Hadjistavropoulos T. Development and preliminary validation of the pain assessment checklist for seniors with limited ability to communicate (PACSLAC). Pain Manag Nurs. 2004;5(1): 37-49.

95. Schnakers C, Chatelle C, Majerus S, Gosseries O, De Val M, Laureys S. Assessment and detection of pain in noncommunicative severely braininjured patients. Expert Rev Neurother. 2010;10(11):1725-1731.

96. Webster J, Bollen P, Grimm H, Jennings M; Steering Group of the RETHINK Project. Ethical implications of using the minipig in regulatory toxicology studies. J Pharmacol Toxicol Methods. 2010;62(3): $160-166$.

97. Boyd Group. The Use of Non-Human Primates in Research and Testing. Wheathampstead, UK: University Federation for Animal Welfare; 2002.

98. National Research Council. Definition of Pain and Distress and Reporting Requirements for Laboratory Animals: Proceedings of the Workshop Held June 22, 2000. Washington DC: The National Academies Press; 2000.

99. Oldham JG. Clinical measurement of pain, distress and discomfort in pigs. In: Gibson TE, Paterson DA, editors. The Proceedings of the Animal Welfare Foundation's Second Symposium - The Detection and Relief of Pain in Animals. London, UK: British Veterinary Association Animal Welfare Foundation; 1985:89-91.
Journal of Pain Research

\section{Publish your work in this journal}

The Journal of Pain Research is an international, peer-reviewed, open access, online journal that welcomes laboratory and clinical findings in the fields of pain research and the prevention and management of pain. Original research, reviews, symposium reports, hypothesis formation and commentaries are all considered for publication.

\section{Dovepress}

The manuscript management system is completely online and includes a very quick and fair peer-review system, which is all easy to use. Visit http://www.dovepress.com/testimonials.php to read real quotes from published authors. 